\title{
Latihan Kegel Exercise Efektif Untuk Mengatasi Inkotinensa Urin Pada Pasien Post Operasi Prostatectomy
}

\author{
Ratna Yunita Sari ${ }^{1}$ \\ Riska Rohmawati ${ }^{2}$ \\ Imamatul Faizah $^{3}$ \\ Fakultas Keperawatan dan Kebidanan, Universitas Nahdlatul Ulama Surabaya ${ }^{1,2,3}$ \\ e-mail corespondeing:ratna@unusa.ac.id
}

\begin{tabular}{l} 
Akuntansi Bisnis dan \\
Manajemen (ABM), \\
\hline Volume 7 \\
Nomor 2 \\
Halaman 1-7 \\
Bulan Desember, \\
Tahun 2020 \\
ISSN 2477-6432 \\
E-ISSN 2721-141X
\end{tabular}

Informasi Artikel

Tanggal Masuk:

1 Sept 2020

Tanggal Revisi:

1 Okt 2020

Tanggal Diterima:

1 Nov 2020
Inkontinensia urin merupakan masalah utama bagi pasien post operasi prostatectomy. Keadaan ini menimbulkan berbagai permasalahan, yaitu masalah medik berupa iritasi dan kerusakan kulit disekitar kemaluan akibat urin, masalah sosial berupa perasaan malu, dan mengurung diri dirumah. Pemakaian pampers atau perlengkapan lain untuk menjaga supaya tidak selalu basah oleh urin akan memerlukan biaya yang tidak sedikit sehingga menambah masalah ekonomi. Solusi yang dapat diberikan adalah latihan kegel exercise yang dapat membantu melatih otot panggul sehingga memperbaiki kemampuan berkemih. Metode pelaksanaan yaitu dengan memberikan ceramah diskusi dan tanya jawab tentang inkontinensia urin dan latihan kegel exercise, serta melakukan praktik tidak langsung dengan cara visualisasi video latihan kegel exercise yang berisikan tentang bagaimana gerakan yang harus dilaksanakan selama proses latihan pada pasien post operasi prostatectomy di RSI Jemursari Surabaya. Berdasarkan hasil pretest dan posttest yang diikuti oleh 30 responden hampir seluruhnya menunjukkan adanya peningkatan pengetahuan responden, dimana responden mengerti dan memahami mulai dari pengertian hingga cara pelaksanaan latihan kegel exercise yang berguna untuk mencegah dan mengatasi inkontinensia urin yang muncul setelah dilakukan operasi prostat. Kesimpulannya yaitu edukasi latihan kegel exercise yang dilaksanakan membantu melatih otot dasar panggul yang akan memperbaiki masalah inkontinensia yang muncul setelah dilakukan operasi prostatectomy.

Kata kunci: Kegel Exercise, Inkontinensia Urin, Post Operasi Prostatectomy

\begin{abstract}
Urinary incontinence is a major problem for postoperative prostatectomy patients. This situation raises various problems, namely medical problems in the form of irritation and skin damage around the genitals due to urine, social problems in the form of feelings of shame, and confining themselves at home. The use of pampers or other equipment to keep the urine from getting wet will always require a significant amount of money, which can add to the economic problem. The solution that can be given is Kegel exercises that can help train pelvic muscles to improve the ability to urinate. The implementation method is by giving a lecture-discussion and question and answer about urinary incontinence and Kegel exercise exercises, as well as indirect practice by visualizing Kegel Exercise video videos that contain about how the movements should be carried out during the exercise process in patients post prostatectomy surgery at RSI Jemursari Surabaya. Based on the results of the pretest and posttest which was attended by 30 respondents almost all showed an increase in respondents' knowledge, where respondents understood and understood from understanding how to implement Kegel exercises that are useful for preventing and overcoming urinary incontinence that arises after prostate surgery. The conclusion is education Kegel exercise that is carried out helps train pelvic floor muscles which will correct incontinence problems that arise after prostatectomy surgery.
\end{abstract}

Keywords: Kegel Exercise, Post Prostatectomy Surgery, Urinary Incontinence 


\section{PENDAHULUAN}

Inkontinensia urin merupakan masalah utama yang dirasakan bagi pasien post operasi prostatectomy pada saat kontrol pertama setelah dilakukan pelepasan selang kateter [1]. Inkontinensia urin yang dialami setelah pelepasan kateter diakibatkan oleh otot detrusor kandung kemih yang tidak secara aktif mengkontraksikan dinding kandung kemih pada proses pengosongan urin akibat dari pemasangan kateter urin jangka lama sejak pasien mengalami masalah berkemih sampai dengan menjalani operasi [2][3]. Hal ini akan mengakibatkan urin mengalir keluar kandung kemih melalui kateter urin secara terus menerus sehingga detrusor tidak dapat segera merespon untuk mengosongkan kandung kemih ketika kateter dilepas. Kondisi ini disebut instabilitas detrusor pasca kateterisasi. Setelah kateter dilepas, terdapat beberapa kemungkinan yang akan dialami oleh pasien berhubungan dengan proses dan reflek berkemihnya. Efek samping dari pemasangan kateter adalah terjadinya inkontnensia urin [4][5]. Selain itu pasca operasi prostatectomy mengakibatkan komplikasi salah satunya adalah inkontinnensia urin, dimana keadaan ini menimbulka berbagai permasalahan mulai dari masalah medis, social, ekonomi sampai penurunan kualitas hidup pasien [6][7].

Menurut O'Callaghan (2017) melaporkan bahwa kasus terjadinya inkontinensia urin pada pasien post operasi prostatectomy dengan pravelensi 2\%-66\% [8]. Selain itu inkontinensia urin awal dapat terjadi 30-40\% dari pasien yang telah melakukan operasi prostatectomy yang disebabkan oleh gejala iritatif seperti penyembuhan fossa atau ketidakstabilan otot kandung kemih akibat dari pembesaran prostat yang lama. Jika hal ini tidak segera diatasi maka 2-4\% dari beberapa pasien dapat menderita inkontinensia total [9]. Hal ini sejalan dengan kejadian pasien post operasi prostatectomy yang pernah dirawat diruangan Azzara 2 RSI Jemursari Surabaya bahwa setelah pelepasan kateter setengah dari pasien merasakan masalah dalam reflek berkemih yang berjumlah 15 orang dari 30 orang yang kontrol di poli urologi pada periode bulan Juli 2019.

Metode non invansif disarankan terlebih dahulu untuk dilakukan pada pasien yang mengalami inkontinensia urin [10][11]. Tindakan yang dapat dilakukan untuk mencegah dan mengatasi gangguan inkontinensia urin yaitu menggunakan metode terapi perilaku noninvansif yang salah satunya adalah melakukan latihan kegel exercise. Dimana metode ini mudah dilakukan, tidak mengelurkan biaya, efektif dan tidak memliki efek samping [12]. Kegel exercise merupakan suatu latihan yang berguna mempertahankan kekuatan otot dasar panggul dan mengkontraksikan otot detrusor kandung kemih sehingga meminimalkan inkontinensia urin [2].

Menurut Sayılan \& Özba (2018) menjelaskan bahwa latihan kegel exercise secara rutin setiap hari setelah pasien menjalani operasi prostatectomy menunjukkan adanya hasil perbaikan kemampuan berkemih dengan ditandai oleh penurunan keluhan dribbling setelah berkemih serta penurunan episode inkontinensia urin setelah post operasi prostatectomy [1]. Hal ini didukung oleh Sari bahwa sangat penting edukasi diberikan sebelum dan sesudah bagi pasien post operasi prostatectomy terutama edukasi latihan kegel exercise yang berguna untuk membantu pasien dalam mencegah dan mengatasi masalah inkontinensia urin setelah pelepasan kateter pasca operasi [13]. Oleh karena itu penyuluhan kesehatan merupakan salah satu metode prefentiv dalam pendidikan kesehatan untuk meningkatkan pengetahuan sehingga kegiatan pengabdian ini akan melakukan penyuluhan kesehatan kepada pasien post operasi prostatectomy dengan tema latihan kegel exercise efektif untuk mengatasi inkontinensia urin pada klien post operasi prostatectomy di RSI Jemursari Surabaya.

Tujuan kegiatan pengabdian ini ialah untuk meningkatakan pemahaman pasien post operasi prostatectomy tentang masalah inkontinensia urin dan latihan kegel exercise mulai dari pengertian sampai dengan tata cara pelaksanan dan gerakan pada saat melakukan latihan kegel exercise secara mandiri dirumah untuk mencegah dan mengatasi masalah inkontinensia urin yang merupakan salah satu komplikasi yang timbul setelah post operasi prostatectomy. 


\section{METODE PELAKSANAAN}

Pelaksanaan kegiatan pengabdian masyarakat dengan latihan kegel exercise efektif untuk mengatasi inkontinensia urin pada pasien klien post operasi prostatectomy dilaksanakan pada bulan Agustus 2019 di RSI Jemursari Surabaya. Secara teknis metode pelaksanaan melalui tahapan pra kegiatan, tahap pelaksanaan kegiatan dan tahap evaluasi. Pada proses tahapan pra kegiatan hal yang dilakukan: 1) rapat strategi pelaksanaan yang melibatkan pihak rumah sakit RSI Jemursari Surabaya bagian diklat keperawatan mulai dari surat izin, penentuan tempat pelaksanaan dengan memakai ruangan azzara 2 yang merupakan ruangan dengan kasus pasien post operasi prostatectomy terbanyak di RSI Jemursari, dan penetapan jadwal pelaksanaan penyuluhan 2) survey lokasi yang akan dilaksanakan penyuluhan satu hari sebelum dilaksanakan kegiatan untuk mengatur tata letak perlengkapan dan bentuk kegiatan, 3) persiapan sarana dan prasarana materi penyuluhan.

Materi penyuluhan yang diberikan, berisi pengetahuan tentang inkontinensia urin yang terdiri dari pengertian, klasifikasi, penyebab, pengobatan dan terapi sedangkan kegel exercise terdiri dari definisi, manfaat, inidikasi kontraindikasi latihan, kapan dilaksanakan latihan sampai tatacara kegel exercise yang disampaikan melalui dengan media lembar balik, leafleat dan video.

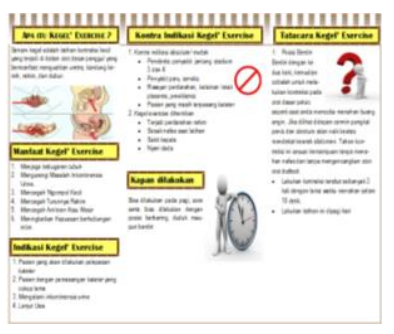

(a)

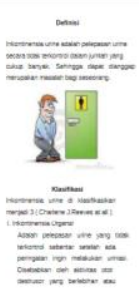

(b)

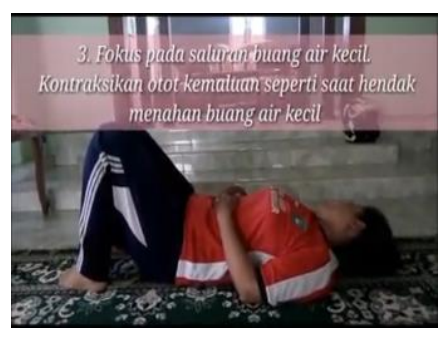

(c)

Sumber: Dokumentasi Pribadi

Gambar 1. (a) Leafleat Kegel Exercise,(b) Leafleat Inkontinesia Urin, (c)

Video Latihan Kegel Exercise

Pada tahap pelaksanaan kegiatan, penyuluh bekerjasama dengan kepala ruangan untuk memberikan informasi tentang kegiatan yang akan dilaksanakan kepada pasien post operasi prostatectomy. Kegiatan penyuluhan dilaksanakan di kamar dan pasien berada pada bed masing-masing. Sebelum dilaksanakan kegiatan dilakukan pengisisan identitas diri dan pretest terlebih dahulu terkait dengan pengetahuan tentang inkontinensia urin dan latihan kegel exercise. Setelah dilakukan pre-test peserta dibagikan materi IPTEK yang sudah disediakan dengan berupa media leafleat dan video yang diberikan kepada masing-masing pasien post operasi prostatectomy sebelum dijelaskan oleh pemateri. Kegiatan pelaksanaan penyuluhan oleh tim pengabdi dilakukan dengan estimasi waktu $\pm 30-40$ menit dengan menyampaikan materi inkontinensia urin mulai dari pengertian sampai terapi dan materi latihan kegel exercise mulai dari pengertian sampai tahap melaksanakan praktik secara tidak langsung menggunakan visualisasi video tahapan gerakan latihan kegel exercise. Setelah kegiatan penyuluhan diadakan sesi diskusi dan post-test, dengan menanyakan atau meriview kembali materi yang telah diberikan untuk melihat seberapa pemahaman atau penyerapan materi penyuluhan yang telah diberikan. 

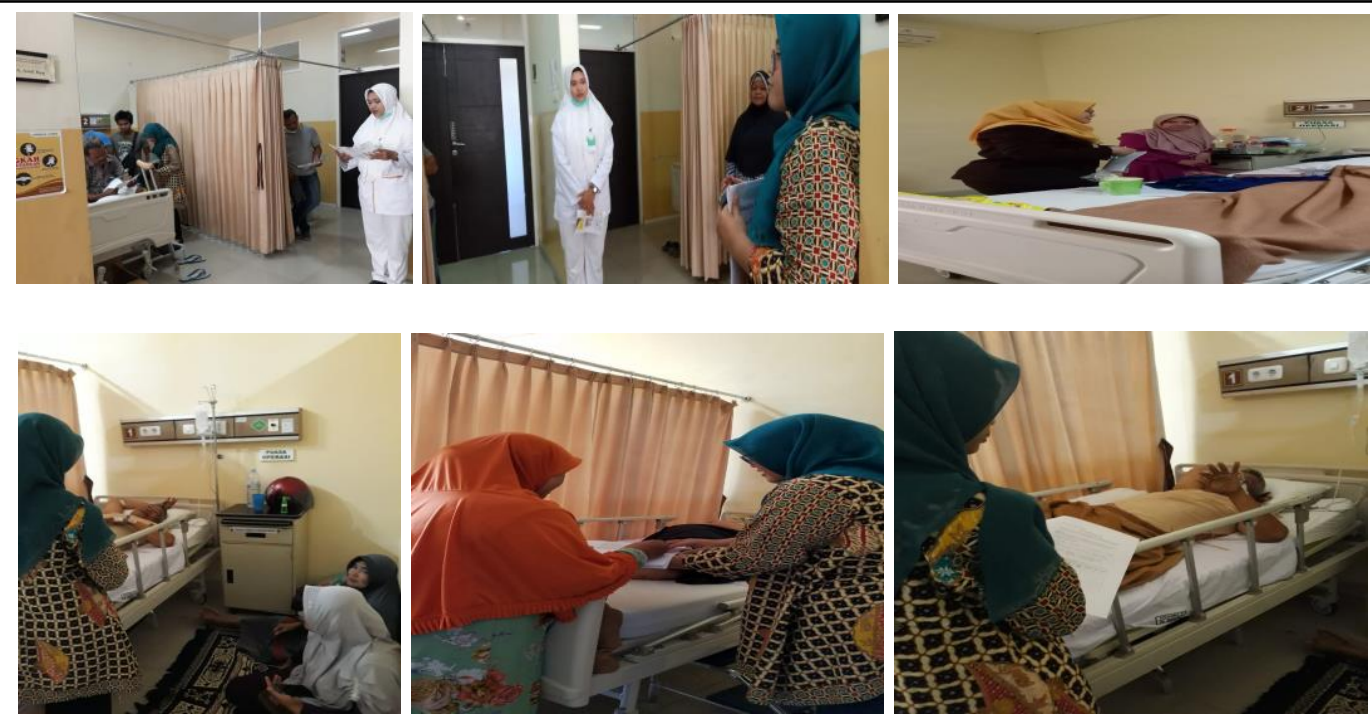

Sumber: Dokumentasi Pribadi

Gambar 2. Pelaksanaan Pengabdian Masyarakat pada Pasien Post Operasi Prostatectomy

\section{PEMBAHASAN}

Kegiatan pengabdian masyarakat ini telah dilaksanakan selama bulan agustus tahun 2019. Kegiatan tersebut melibatkan 30 pasien post operasi prostatectomy di RSI Jemursari Surabaya dengan kegitan berlangsung selama kurun waktu \pm 30 - 40 menit selama bulan Agustus 2019. Adapun karakteristik peserta yang ikut berpartisipasi dalam kegiatan penyuluhan dijabarkan pada Tabel 1 .

Tabel 1. Distribusi Frekuensi Karakteristik Responden

\begin{tabular}{lcc}
\hline \multicolumn{1}{c}{ Variabel } & \multicolumn{2}{c}{ Responden $\mathrm{n}(30)$} \\
\cline { 2 - 3 } Usia & $\mathrm{f}$ & $\%$ \\
$\begin{array}{l}\text { Dewasa akhir (36-45 } \\
\text { tahun) }\end{array}$ & 5 & 16,1 \\
Lansia awal (46-55 tahun) & 10 & 32,3 \\
Lansia akhir (56-65 tahun) & 15 & 50,0 \\
\hline Tingkat Pendidikan & & \\
Pendidikan Dasar & 4 & 13,3 \\
Pendidikan Menengah & 8 & 66,7 \\
Pendidikan Tinggi & 9 & 20,0 \\
\hline Status Pekerjaan & & \\
Bekerja & 19 & 63,3 \\
Tidak bekerja & 11 & 36,7 \\
\hline
\end{tabular}

Sumber: Data Primer, 2019

Berdasarkan tabel 1. didapatkan hasil bahwa setengah dari (50\%) peserta penyuluhan berada pada rentang usia 56-65 tahun atau usia lansia akhir. hal ini sejalan dengan pernyataan dari Potter, Perry, Stockert, \& Hall (2016) menyatakan pembesaran prostat merupakan konsisi yang umum terjadi kepada laiki-laki dengan rentang usia lebih dari 50 tahun yang akan menyebabkan terjadinya gejala gangguan saluran urinaria yang disebabkan oleh adanya pembentukan nodul besar pada kelenjar prostat yang dapat menekan uretra dan menyebabkan obtruksi dan irigasi [14]. Selain itu tindakan pembedahan prostatectomy yang dijalani juga akan menimbulkan komplikasi setelahnya yaitu masalah inkontinensia urin. Inkontinensia urin sendiri merupakan masalah ketidakmampuan seseorang dalam mengontrol urin yang ditandai dengan urin yang menetes setelah miksi dimana kondisi ini paling sering dikeluhkan oleh pasien setelah pelepasan kateter urin post operasi prostatectomy [12][15]. Permasalahan ini sangat penting untuk diatasi mengingat bahwa pasien prostat berada pada rentang usia 
dewasa akhir sampai lansia akhir dimana terjadinya penurunan fisik serta perubahan mekanisme didalam tubuh dan dengan kondisi pemakaian kateter urin yang cukup lama yang akan membuat penurunan pada otot detrusor untuk berkontraksi untuk mengeleminasi urinnya[12]. Hal ini dapat diatasi dengan latihan kegel exercise, dimana latihan mempunyai manfaat dalam penguatan otot Pubococsigeus secara sadar dengan melakukan gerakan kontraksi berulang-ulang untuk menurunkan inkontinensia urin [1]

Pada tingkat pendidikan sebagian besar $(66,7 \%)$ pasien memiliki latar belakang pendidikan tingkat menengah dan juga sebagaian besar $(63,3 \%)$ masih aktif bekerja. Selama proses pelaksanaan kegiatan peserta sangat antusias dengan materi apa yang akan disampaikan karena akan mendapatkan sebuah solusi untuk mencegah dan mengatasi masalah inkontinensia urin yang akan dialami setelah post operasi prostatectomy dan pelepasan kateter urin secara mandiri tanpa ada tindakan invansif dan komplikasi pada tindakan latihan yang akan dilakukan didukung lagi dengan video praktik latihan kegel exercise sehingga dapat menjadi instruktur secara tidak langsung pada saat proses latihan. Selain itu, hampir setengah peserta penyuluhan mengungkapkan bahwa jika inkontinensia urin terjadi pada dirinya setelah pelepasan kateter maka akan merasa kurang percaya diri saat beraktvitas maupun bekerja sehingga menurunkan kualitas hidupnya. Setelah proses penyuluhan yang telah dilaksanakan, sebagai proses evaluasi kegiatan, maka dilakukan pengukuran tingkat pengetahuan tentang inkontinensia urin dan latihan kegel exercise terhadap pasien. Adapun perbedaan tingkat pengetahuan paisen post operasi prostatectomy sebelum dan sesudah penyuluhan ditampilkan pada tabel 2 sebagai berikut:

Tabel 2. Perbedaan pengetahuan tentang pengetahuan latihan kegel exercise efektif untuk mengatasi inkontinensia urin sebelum dan sesudah penyuluhan

\begin{tabular}{lcccc}
\hline Tingkat Pengetahuan & \multicolumn{2}{c}{ Sebelum } & \multicolumn{2}{c}{ Sesudah } \\
\cline { 2 - 5 } & $\mathrm{n}$ & $\%$ & $\mathrm{~N}$ & $\%$ \\
\hline Rendah & 26 & 86,7 & 3 & 10.0 \\
Sedang & 4 & 13,3 & 18 & 60,0 \\
Tinggi & 0 & 0 & 9 & 30,0 \\
\hline Jumlah & 30 & 100 & 30 & 100 \\
\hline Wilcoxon & & $P=0,000$ & &
\end{tabular}

Sumber: Data Primer, 2019

Pada tabel 2. Menunjukkan bahwa adanya peningkat pengetahuan pada peserta yang berpartisipasi dalam kegiatan pengabdian masyarakat tentang latihan kegel exercise yang dapat mengatasi inkontinensia urin pada pasien post operasi prostatectomy. Hasil pengabdian didapatkan bahwa sebelum penyuluhan hampir seluruhnya pasien memiliki tingkat pengetahuan rendah, dimana pasien hanya 5 orang saja $(16,6 \%)$ yang mengerti mengenai pengertian inkontinensia urin namun jika ditanya tentang penyebab, pengobatan dan terapi yang dapat mengatasi peserta tidak dapat menjawab dengan benar. Selain itu, semua pasien belum pernah mengetahui atau mendengar mengenai latihan kegel exercise yang dapat mencegah atau mengatasi masalah inkontinensia urin akibat dampak dari post operasi prostatectomy. Setelah diberikan penyuluhan pengetahuan peserta berubah dengan hampir seluruhnya memiliki tingkat pengetahuan mulai darisedang sampai tinggi. Dimana pasien sudah dapat memahami tentang latihan kegel exercise yang dapat mengatasi inkontinensia urin mulai dari pengertian sampai dengan tahap gerakan yang dilakukan dalam latihan.

Pemahaman materi yang diterima baik oleh pasien dalam kegiatan pengabdian masyarakat tidak terlepas dari latar belakanng pendidikan pasien dimana sebagaian besar memiliki tingkat pendidikan menengah. Menurut Notoatmodjo (2007) menyatakan bahwa semakin tinggi tingkat pendidikan yang di miliki oleh seseorang maka semakin cepat dan tanggap dalam menerima informasi sehingga akan membentuk sikap dan perilaku hidup sehat 
[16]. Setelah kegiatan pengabdian masyarakat selesai dilaksanakan hampir seluhruhnya pasien mengungkapkan rasa syukur dengan edukasi yang telah diberikan sehingga mengurangi tingkat kecemasan akibat ketidaktahuan yang akhirnya membut membayangkan hal yang tidak-tidak terkait kondisinya setelah pasca operasi serta ada perasaan puas terhadap pelayanan yang diberikan selama dirawat. Hal ini sejalan dengan pernyataan dari Sari (2019) yang menyatakan pentingnya edukasi yang diberikan selama pelayanan asuhan keperawatan sebelum dilakukan tindakan operasi sampai masa perawatan pasien karena edukasi yang diberikan akan membuat pasien tahu tentang kondisinyasehingga membuat lebih tenang dan status hemodinamik lebih stabil. Dimana status hemodinamik yang stabil akan mempengaruhi keberhasilan operasi dan proses penyembuhan [13]. Keberhasilan dari materi yang disampaikan tidak terlepas dari penyesuaian kebutuhan sasaran sehingga pesan yang disampaikan dapat diterima dengan baik [16].

\section{KESIMPULAN}

Kegiatan pengabdian kepada masyarakat yang telah dilaksanakan didapatkan hasil bahwa latihan kegel exercise efektif untuk mengatasi inkontinensia urin pada klien post operasi prostatectomy di RSI Jemursari Surabaya dapat meningkatkan pengetahuan pasien mulai dari pemahaman pasien tentang kondisi inkontinensia urin sampai cara melakukan latihan kegel exercise. Selain itu pelatihan kegel exercise secara praktik tidak langsung menggunakan visualisasi video selama penyuluhan untuk media pembelajaran sangat disenangi oleh pasien karena bisa diulang dan dipraktikkan secara mandiri dirumah yang bermanfaat untuk mencegah dan mengatasi masalah inkontinensia urin post operasi prostatectomy.

\section{DAFTAR PUSTAKA}

A. A. Sayılan and A. Özba, 2018. "The Effect of Pelvic Floor Muscle Training On Incontinence Problems After Radical Prostatectomy," Am. J. Men's Heal., vol. Vol. 12(4), no. 39.

J. I. Chang, V. Lam, and M. I. Patel. 2016. "Preoperative Pelvic Floor Muscle Exercise and Postprostatectomy Incontinence: A Systematic Review and Meta-analysis.," Eur. Urol., vol. 69, no. 3, pp. 460-467, Mar.

R. Y. SARI. 2016. "Penerapan Kegel Exercise Pada Pasien Bph Post Op Turp Dengan Masalah Keperawatan Inkontinensia Urin Di Ruang Azzahra 2 Rumah Sakit Islam Jemursari Surabaya," KIA: Universitas Nahdlatul Ulama Surabaya.

J. M. \& H. J. H. Black. 2014. Medical Surgical Nursing Clinical Managemen for Positive Outcome. St. Louis: Elsevier,

S. L. Lewis, S. R. Dirksen. 2015. M. M. Heitkemper, L. Bucher, and I. Camera, MedicalSurgical Nursing - E-Book: Assessment and Management of Clinical Problems, Single Volume. Elsevier Health Sciences.

Sosnowski R. et al. 2011. "Urinary incontinence after radical prostatectomy - experience of the last 100 cases.," Cent. Eur. J. Urol., vol. 64, no. 4, pp. 213-217.

L.-F. Hsu, Y.-M. Liao, F.-C. Lai, and P.-S. Tsai. 2016. "Beneficial effects of biofeedbackassisted pelvic floor muscle training in patients with urinary incontinence after radical prostatectomy: A systematic review and metaanalysis.," Int. J. Nurs. Stud., vol. 60, pp. 99-111, Aug.

M. E. O'Callaghan et al.. 2017. "Tools for predicting patient-reported outcomes in prostate cancer patients undergoing radical prostatectomy: a systematic review of prognostic accuracy and validity.," Prostate Cancer Prostatic Dis., vol. 20, no. 4, pp. 378-388, Dec.

R. Sjamsuhidajat and W. De Jong. 2019. "Buku-Ajar Ilmu Bedah," Jakarta: Bumi Aksara.

H. C. Frawley, S. G. Dean, S. C. Slade, and E. J. C. Hay-Smith. 2017. "Is Pelvic-Floor Muscle Training a Physical Therapy or a Behavioral Therapy? A Call to Name and 
Report the Physical, Cognitive, and Behavioral Elements," Phys. Ther., vol. 97, no. 4, p. 425-437, Apr.

V. Ficarra et al.. 2013. "Long-term evaluation of survival, continence and potency (SCP) outcomes after robot-assisted radical prostatectomy (RARP)," BJU Int., vol. 112, no. 3, p. 338-345, Aug.

D. S. Mina et al. 2014. "Prehabilitation for men undergoing radical prostatectomy: a multicentre , pilot randomized controlled trial," BMC Surg., vol. 14:89, pp. 1-8, 2014.

R. Y. Sari, R. Rohmawati, I. Faizah, and W. Heris. 2020. "Pengaruh Pre-Operative Teaching Islami Terhadap Tingkat Cemas Pasien Pre-Operasi TUR-P di RSI Jemursari Surabaya," J. Ilm. Keperawatan, vol. 15, no. 1, pp. 66-77.

P. A. Potter, A. G. Perry, P. Stockert, and A. Hall. 2016. Fundamentals of Nursing - E-Book. Elsevier Health Sciences.

K. Matsushita et al. 2015. "Preoperative predictive model of recovery of urinary continence after radical prostatectomy.," BJU Int., vol. 116, no. 4, pp. 577-583, Oct.

S. Notoatmodjo, 2017. "Promosi kesehatan dan ilmu perilaku," Jakarta: rineka cipta, vol. 20, 2007. 